Journal of Applied Pharmaceutical Science Vol. 6 (12), pp. 028-031, December, 2016

Available online at http://www.japsonline.com

DOI: $10.7324 /$ JAPS.2016.601204

ISSN 2231-3354 (cc)) BY-NC-SA

\title{
Antifeedant Constituents from Leucaena leucocephala
}

\author{
Poonam Negi ${ }^{1 *}$, Bhupendra Singh Rawat ${ }^{2}$, Devendra Singh Negi ${ }^{3}$ \\ ${ }^{1}$ Department of Chemistry, Uttaranchal University, Dehradun, India. \\ ${ }^{2}$ Department of Physics, Uttaranchal University, Dehradun, India. \\ ${ }^{3}$ Department of Chemistry, Hemwati Nandan Bahuguna Garhwal University. Srinagar, India.
}

\section{ARTICLE INFO}

Article history:

Received on: 18/07/2016

Revised on: 04/10/2016

Accepted on: 30/10/2016

Available online: 28/12/2016

Key words:

Leucaena leucocephala:

Mimosaceae; Spodoptera

litura; quercetin 3-O-

rhamnoside.

\begin{abstract}
Hexane and methanolic extracts of Leuceana leucocephala Lam. leaves were tested against Spodoptera litura $\mathrm{L}$. a polyphagus pest of cotton rice, tomato, ground nut, castor and legume and found to have antifeedant potential in the concentration of $2.5 \mu \mathrm{g} / \mathrm{cm}^{2}$. The bioassay-guided fractionation yielded the three compounds quercetin 3$O$-rhamnoside (1), quercetin (2) and D-onanitol, (3) with antifeedant activity.
\end{abstract}

\section{INTRODUCTION}

Botanical insecticides have long been used by men since ancient times in insect pest management and crop protection and are attractive alternatives to synthetic chemical insecticides for pest management because of little threat to the environment and human health. The mechanism of action of botanical pesticides may differ greatly and are often not yet well understood. They have an advantage that they combine a wide range of toxic potencies hence reducing the chance of pest to develop resistance (Nelson and William, 2004). In addition to that, residues are hardly expected on the products or in the environment since botanical pesticides are generally considered to be non persistent under field condition as that are readily degraded by light, oxygen and microorganism to less toxic products (Isman and Akhtar, 2007). The deleterious effects of crude plant extracts on insects are manifest in several ways, including toxicity, (Hiremath, 1997) feeding inhibition

\footnotetext{
* Corresponding Author

E-mail:poo.chm20@gmail.com
}

(Wheeler and Isman, 2001). The search for plant derived chemicals that have potential use as crop-protectant (insecticide, antifeedant, and growth inhibitor) often begins with screening of plant extracts (Peta and Pathipati, 2008). Insecticides of plant origin have been in use for long time. By applying plant extracts to other susceptible plant species the defense of susceptible plant is improved and use of natural products in agro ecosystem is emerging as one of the prime means to protect crops (Rattan, 2010). The cutworm, Spodoptera litura Fabricius (Lepidoptera: Noctuidae), is a polyphagous pest that has near about 150 host species. The cutworm, Spodoptera litura is an economically important polyphagous pest found in major part of the world. In India, the larval stages causes severe damage to a number of crops including tobacco, caster, groundnut, tomato, cabbage, cauliflower, cotton and other various crucsiferous crops (Rao et al., 2001) Crop loss due to insect pests varies between $10 \%$ and $30 \%$ for major crops (Ferry et al., 2004; Isman et al., 2007). Traditionally synthetic pesticides are used to control $S$. litura and hence the pest developed resistance against the commonly using pesticides. For this purpose, medicinal plants were screened and are being reported to contain bio-pesticidal property (Selvaraj et al., 2005). 
S. litura is often used to evaluate antifeedants in plants. (Pung and Srimongkolchai, 2011). Number of plants exhibited significant antifeedant activity against this pest. Several Himalayan plants are documented as insecticidal agents against spodoptera littura and other forest pests (Negi et al., 2016; Negi et al., 2006) Extracts of Swertia corymbosa, Phyllanthus deblis, Syzygium lineare, Curculigo orchioides, Evolvulus alsinoides, and Zanthoxylum limonella showed significant antifeedant activity against spodoptera litura (Jeyasankar et al., 2010; Arivoli et. al., 2012). Leucaena leucocephala (Mimosaceae) Lam. (Shu babol) is an unarmed small deciduous tree to $5 \mathrm{~m}$ height, generally used for soil conservation, fuel and feed purposes in India.(Gaur, 1999) It was known to be a rich source of tannin, proteinous and nonproteinous amino acid and other phenolics (Azeemoddin et al., 1988; Hossain et al., 1998). The plant commonly used as foliage, as a source of $\beta$-carotene, vitamin $\mathrm{K}, \beta$-carotene, green manure, fuel wood or as drought resistance (Lalitha et al., 1993). It is also known to have great medicinal importance (Salem et al., 2011). The roots of Leucaena leucocephala contains tannins which are known to exhibited nitrification inhibition effect (Erickson et al., 2000). The seed oil could be used as a potential bio inhibitor for corrosion of mild steel and copper.(Meena et al., 2013). The phytochemical investigation of Leucaena leucocephala revealed the presence of coumarins, terpenes, sterols and flavonoids. The seed extract of Leucaena leucocephala have been reported as antidiabetic, anthelmintic and has a broad spectrum antibacterial activity (Irene et al., 1997; Ademola et al., 2005; Syamsudin et al., 2010). The significant antioxidant activity and antimicrobial activity was recorded from the extract and the compounds isolated from Leucaena leucocephala (Reda et al., 2015).

In present investigation, we tested the antifeedant level of plant extract of Leucaena leucocephala and isolated compounds of Leucaena leucophela against third instar larvae of S. litura. (Lapidoptera), a polyphagous pest of groundnut, tomato, cotton, rice, tobacco, castor and legumes.

\section{MATERIAL AND METHODS}

\section{General Experimental Procedure}

Melting points is uncorrected and was taken in open capillary. NMR spectra were recorded at $400 \mathrm{MHz}$ for ${ }^{1} \mathrm{H}$ and 100 $\mathrm{MHz}$ for ${ }^{13} \mathrm{C}$ on Bruker AVANCE 400 spectrometer in DMSO- $d_{6}$, $\mathrm{CDCl}_{3}$ with TMS as internal standard. Proton detected heteronuclear correlation were measured using HMQC (optimized for ${ }^{1} J_{\mathrm{HC}}=145 \mathrm{~Hz}$ ) and $\mathrm{HMBC}$ (optimized for $J_{\mathrm{HCCC}}=7 \mathrm{~Hz}$ ). The IR spectra were recorded on a Perkin Elmer Infrared 15 spectrometer using $\mathrm{KBr}$ pellets. MS data were obtained on a JEOL SX-102 spectrometer. Silica gel (60-120 mesh Merck) for column chromatography and silica gel G (Merck) for TLC were used.

\section{Plant Material}

Leaves of Leucaena leucocephala were collected at Chauras campus of HNB Garhwal University, Srinagar Garhwal, Uttarakhand, India. A voucher specimen (GUH 16280) is deposited in the Herbarium of Chemistry Department HNB Garhwal University, Srinagar Garhwal, Uttarakhand, India.

\section{Pest}

Field collected Spodoptera litura L. larvae were cultivated in the laboratory at $25 \pm 2^{\circ} \mathrm{C}$ and third instar larvae from laboratory culture were used for antifeedant assay.

\section{Extraction and Isolation}

Shed dried powder leaves part $(2.4 \mathrm{~kg})$ was exhaustively extracted at $60^{\circ} \mathrm{C}$ with $90 \% \mathrm{EtOH}$. The extract was evaporated in vacuo to give the crude residue A-1. It was partitioned with hexane and methanol, and gave hexane-soluble fraction, A-2 and methanol-soluble fraction, A-3. A-3 was charged to gross chromatography on silica gel using $\mathrm{CHCl}_{3}-\mathrm{MeOH}$ as eluent with increasing proportion of methanol, which afforded Fr 01 and $\mathrm{Fr}$ 02. Fr 01 was re-chromatographed on $\mathrm{CC}$ using $\mathrm{CHCl}_{3}-\mathrm{MeOH}$ (9:1) afforded $\mathbf{1}$ (45mg) and $\mathbf{2}$ (18mg), while Fr 02 gave $\mathbf{3}$ (108mg) further purified by $\mathrm{MeOH}$.

Quercetin 3-O-rhamnoside (1) was isolated as yellow solid from $\mathrm{CHCl}_{3}-\mathrm{MeOH}(9: 1), 45 \mathrm{mg}, \mathrm{mp} 208^{\circ} \mathrm{C}, \quad \mathrm{IR}(\mathrm{KBr}) v_{\max } \mathrm{cm}^{-1}$ : 3465(OH), 1664(lactone $\mathrm{C}=\mathrm{O}), 1596$ (aromatic), 824; ${ }^{1} \mathrm{H}$ NMR and ${ }^{13} \mathrm{C}$ NMR data, see Table 1; HRMS: 448.4741 calcd for 448.3769 .

Quercetin (2) was obtained as yellow solid from $\mathrm{CHCl}_{3}-\mathrm{MeOH}$ (9:1),18 mg, mp 313-314 $\mathrm{C}$, IR (KBr) $v_{\max } 3470(\mathrm{OH})$, 1645(lactone $\mathrm{C}=\mathrm{O}$ ), $840 \mathrm{~cm}^{-1}$; HRMS: 302.3214 calcd for 302.2357 .

D-Onanitol (3) was isolated as white solid from $\mathrm{CHCl}_{3}-\mathrm{MeOH}$ (9:1), 108mg, IR (KBr) $v_{\max }: 3378,1070,711 \mathrm{~cm}^{-1}$; HRMS : 194.2145 calcd for 194.1825 .

\section{Antieedant Activity}

Crude extract and isolated compounds were tested against third instar larvae of Spodoptera litura L. (Lepidoptera). The dual choice leaf disc method was performed (Kannan, et al., 2013). Field collected Ricinius communis leaves were cut in to circular discs $\left(180 \mathrm{~cm}^{2}\right)$ with the medium vain as marker between two equal halves. Hexane and methanolic extracts and isolated compounds were dissolved in solution, which was sprayed on half of circular leaf disc with $2.5-\mu \mathrm{g} / \mathrm{cm}^{2}$ concentrations. Other half of the leaf treated with solvent.

Azadirachtin A, a potent insect antifeedant and growth regulatory compound, was kept as active control (Govindachari, et al., 1995; Govindachari, et al., 1996). After drying, each leaf disc was placed in a Petri dish (15 cm dia). Five freshly moulted insect third instar larvae of $S$. litura were placed in the center of leaf and left to feed for $36 \mathrm{hr}$. For each extracts and compounds, five replicate were maintained. After $24 \mathrm{hrs}$ the leaves were removed 
and unfed area in the treated and control halves were measured using $\Delta \mathrm{T}$ area measurement meter.

Percent feeding index (PFI) was calculated as:

$\mathrm{PFI}=\frac{\% \text { area fed in treated }}{\% \text { area fed in treated }+\% \text { area fed in control }} \mathrm{X} 100$

\section{RESULTS AND DISCUSSION}

Compound 1 was isolated as yellow solid. The highresolution mass spectroscopy gave molecular mass 448.4741 suggested for $\mathrm{C}_{21} \mathrm{H}_{20} \mathrm{O}_{11}$. A positive Shinoda test and $\mathrm{FeCl}_{3}$ color reaction suggested it as phenolic flavonoid. The ${ }^{1} \mathrm{H}-\mathrm{NMR}$ spectrum showed signal for 20 protons including two doublets at $\delta$ 6.19 and $6.36(J=2.0 \mathrm{~Hz})$ as $\mathrm{H}-6$ and $\mathrm{H}-8$, two downfield doublets 7.30 and 7.32 for $\mathrm{H}^{-5}$ ' and $\mathrm{H}-2$ ' one double doublet 6.91 assigned for $\mathrm{H}-6$ ' respectively. Anomeric proton $\mathrm{H}-1$ ', , detected at $\delta 5.34$ with coupling constant of $1.0 \mathrm{~Hz}$ and a doublet methyl signal at $\delta$ $0.84(J=6.0 \mathrm{~Hz})$ suggested sugar is rhamnose. Exact proton and carbon positions were confirmed by COSY, DQF HSQC and HMBC experiments. Since in the HMBC spectrum, an anomeric H-1" showed long-range coupling with C-3 $(\delta$ 136.23) and C2 ' $(\delta 72.10)$, the exact position of rhamnose was confirmed to be at C-3. Further acid hydrolysis of $\mathbf{1}$ gave aglycone and sugar identified as rhamnose by comparison of co-TLC with that of authentic sample. On the basis of above data and its comparison with data reported in literature compound 1 was identified as 2 (3,4-dihydroxyphenyl)-5,7-dihydroxy-3-[(2S,3R,4R,5S,6S)-3,4,5trihydroxy-6-methyl-oxan-2-yl]oxy-chromen-4-one(Lowry et al., 1984) (Table 1).

Table 1: ${ }^{1} \mathrm{H}$ and ${ }^{13} \mathrm{C}$ data and $\mathrm{HMBC}$ correlation of $\mathbf{1}$

\begin{tabular}{|c|c|c|c|c|}
\hline \multirow{2}{*}{$\begin{array}{c}\mathrm{H} / \mathrm{C} \\
\text { atom }\end{array}$} & \multirow{2}{*}{$\begin{array}{c}{ }^{13} \mathrm{C} \delta \\
\mathrm{Hz} \text { in }\end{array}$} & \multirow{2}{*}{$\begin{array}{c}{ }^{1} \mathbf{H} \boldsymbol{\delta} \\
J \text { in } \mathbf{H z}\end{array}$} & \multicolumn{2}{|c|}{ HMBC } \\
\hline & & & ${ }^{2} J$ & ${ }^{3} \boldsymbol{J}$ \\
\hline 2 & 158.52 & - & - & - \\
\hline 3 & 136.23 & - & - & - \\
\hline 4 & 179.64 & - & - & - \\
\hline 5 & 163.23 & - & - & - \\
\hline 6 & 99.76 & $6.19(\mathrm{~d}, J=2.0)$ & C-5,C-7 & C-8,C-4a \\
\hline 7 & 165.86 & - & - & - \\
\hline 8 & 94.69 & $6.36(\mathrm{~d}, J=2.0)$ & $\mathrm{C}-7$ & C-6,C-4a,C-2 \\
\hline $4 a$ & 105.89 & - & - & - \\
\hline $8 a$ & 159.31 & - & - & - \\
\hline 1 , & 122.85 & - & - & - \\
\hline 2 , & 116.91 & $7.32(\mathrm{~d}, J=2.5)$ & $\mathrm{C}-1{ }^{\prime}$ & $\mathrm{C}-5^{\prime}, \mathrm{C}-4^{\prime}$ \\
\hline $3^{\prime}$ & 116.35 & - & - & - \\
\hline $4^{\prime}$ & 149.7 & - & - & - \\
\hline 5 , & 146.41 & $7.30(\mathrm{~d}, J=8.4)$ & $\mathrm{C}-2^{\prime}, \mathrm{C}-4^{\prime}$ & C-6' \\
\hline 6 ' & 122.96 & $6.91(\mathrm{dd}, J=2.5,8.4)$ & $\mathrm{C}-1^{\prime}, \mathrm{C}-5^{\prime}$ & C-3',C-4',C-8a \\
\hline 1 , & 103.54 & $5.34(\mathrm{~d}, J=1.0)$ & $\mathrm{C}-2$, & $\mathrm{C}-3$ \\
\hline 2 ', & 72.10 & $3.43(\mathrm{dd}, J=6.0,8.5)$ & - & C-6', C-4', \\
\hline 3, & 72.03 & $3.32(\mathrm{t}, J=9.0)$ & - & $\mathrm{C}-5^{,}$, \\
\hline 4, & 73.24 & $3.74(\mathrm{t}, J=9.0)$ & C-3, & - \\
\hline 5, & 71.90 & $4.21(\mathrm{q}, J=1.6,3.2)$ & $\mathrm{C}-4$, & $\mathrm{C}-3$, \\
\hline $6 \%$ & 17.65 & $0.87(\mathrm{~d}, J=6.0)$ & $\mathrm{C}-5$, & C-4, \\
\hline
\end{tabular}

Compounds $\mathbf{2}$ and $\mathbf{3}$ were identified as quercetin and Donanitol by comparison of co-TLC with authentic samples and NMR data with those of data reported in literature (Lowry et al., 1984; Dorman et al., 1970) (Fig 1). For antifeedant activity the crude extracts were tested on dual choice leaf disc method to know the Percentage Feeding Index (PFI).

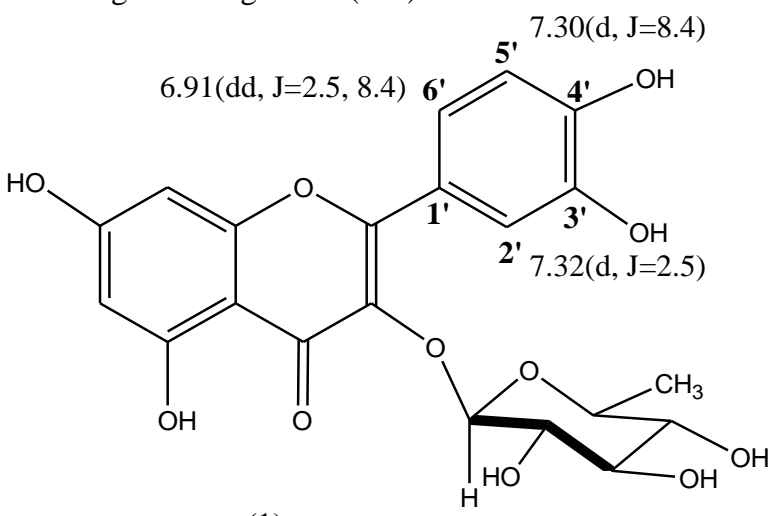

(1)

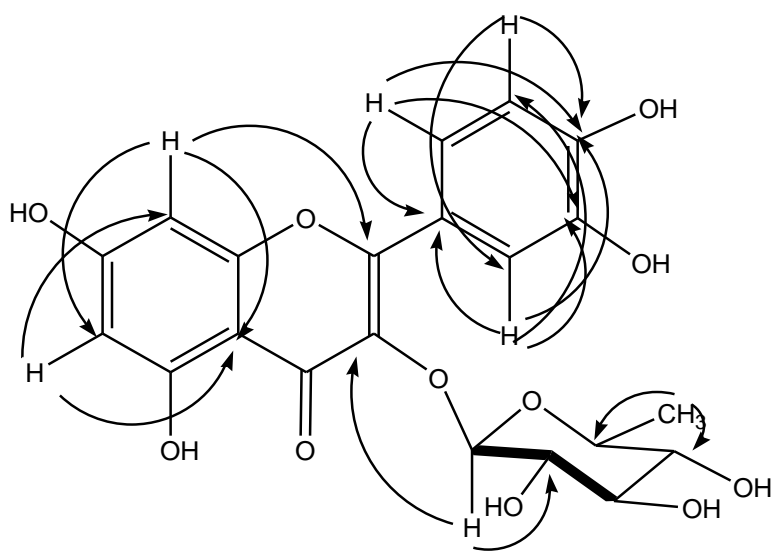

Selected HMBC correlation of compound (1)<smiles>CO[C@H]1[C@@H](O)[C@H](O)[C@H](O)[C@H](O)[C@H]1O</smiles>

(3)

Fig 1: Isolated Compounds : Quercitin 3-O-rhamnoside (1) HMBC Correlation of (1) and D-Onanitol (3)

Table 2: Antifeedant activity of extracts and isolated compounds.

\begin{tabular}{ll}
\hline Particular & Percent Feeding Index (PFI) \\
\hline Hexane extract A02 & $68.24 \pm 4.62$ \\
Methanol extract A03 & $32.68 \pm 2.49$ \\
Quercitin 3-O-rhamnoside (1) & $35.41 \pm 1.64$ \\
Quercitin (2) & $40.10 \pm 6.24$ \\
D-onanitol (3) & $54.18 \pm 8.34$ \\
Azadirachtin A & $16.81 \pm 4.24$ \\
\hline
\end{tabular}

Hexane extract A-2 showed $68.24+4.62$ and methanol extract A-3 showed $32.68+2.49$ PFI. Fraction Fr 01 and Fr 02 
from A-3 exhibited $46.22+1.4$ and $70.12+6.12$ PFI. The Fr 01 fraction led to isolation of two active compound $\mathbf{1 - 2}$ while Fr 02 afforded $\mathbf{3}$ in which $\mathbf{1}$ showed higher antifeedant activity as compared to $\mathbf{2}$ and $\mathbf{3}$ (Table 2).

\section{CONCLUSION}

Flavonol glycoside Quercitin 3-O-rhamnoside along with Quercitin and D-onanitol were isolated from the dried leaves Leucaena leucocephala leaves. Hexane and methanolic extracts and isolated compounds were test for antifeedant activity against spodoptera litura by duel choice leaf disc method and result was evaluated in terms of Percentage feeding index. A comparison of antifeedant activity against $S$. Litura indicated that the methanolic extract and the active compound Quercitin 3-O-rhamnoside expressed significant antifeedant potential. These results could be useful in eco-friendly formulations for insect control.

\section{ACKNOWLEDGEMENTS}

We are thankful to Dr. S. Narasimhan, AHRF, and Chennai for antifeedant assay of the extracts and samples.

Financial support and sponsorship: One of the authors is thankful to DST India for financial assistance.

Conflict of Interests: There are no conflicts of interest.

\section{REFERENCES}

Ademola IO, Akanbi AI, Idowu SO, Comparative nematocidal activity of chromatographic fractions of Leucaena leucocephala seeds against gastrointestinal sheep nematodes Pharmaceutical Biology, 2005; 43(7): 599-604.

Azeemoddin G, Jagan Mohan Rao S, Thirumala-Rao SD, Amino acid composition of subabul (Leucaena leucocephala) seed kernel proteins, J. Food Sci.Technol., 1988; 25: 158.

Erickson AJ, Ramsewak RS , Smucker AJ, Nair MG, Nitrification Inhibitors from the Roots of Leucaena leucocephala. Journal of Agricultural and Food Chemistry, 2000; 48(12): 6174- 6177.

Gaur RD, 1999, Flora of Garhwal District of North West Himalaya, Srinagar India:Trans media Publisher

Govindachari TR, Narasimhan NS, Suresh G, Partho PD, Gopalakrishnan G, Krishna Kumari GN, Structure-related insect antifeedant and growth regulating activities of some limonoids, J. Chem. Ecol. , 1995; 21:1585-1600 .

Govindachari TR, Narasimhan NS, Suresh G, Partho PD, Gopalakrishnan G, Insect antifeedant and growth-regulating activities of Salannin and other c-seco limonoids from neem oil in relation to Azadirachtin, J. Chem. Ecol., 1996;22(8):1453-1461.

Hiremath IG. Insecticidal activity of Indian plant extracts against Nilaparvata lugens, Entomology and Zoology, 1997; 32: 156-166.

Hossain MA, Alam M, Huq MS, Studies on the composition of ipil-ipil (Leucaena leucocephala ) seed oil, Dhaka Univ.Stud, 1998; 36:163-9

Irene MV, Robert MTG, Rosette CG, Bioactivity studies on the alkaloid extracts from seeds of Leucaena leucocephala, Phyto therapy Research, 1997;11(8): 615-617.
Isman MB, Akhtar Y, 2007. Plant natural products as a source for developing environmentally acceptable insecticides. In: I Shaaya, R Nauen, AR Horowitz Eds. Insecticides Design Using Advanced Technologies. Springer, Berlin, Heidelberg pp. 235-248.

Kannan S, Vijayakumar B, Sureshkumar C, Mohankumar R, Narasimhan S, Insect Antifeedant and Growth Regulating Activities of bAmyrin from Sarcostemma acidum, Asian Journal of Chemistry, 2013; 25(2): 1167-1168.

Lalitha K, Vargheese CM, Balasubramanian N, Spectrophotometric determination of mimosine and 3-Hydroxy-4- $(1 \mathrm{H})-$ pyridone - The toxic principles of $L$. leucocephala. Analyt. Biochem, 1993; 213: 57-62.

Lowry JB, Cook N, and Wilson RD, Flavonol glycosides distribution in cultivars and hybrids of Leucaena leucocephala, Journal of the Science of Food and Agriculture, 1984; 35::401-407.

Meena VN, Ariharan VN, Nagendra P, Nutritive Value and Potential Uses of Leucaena leucocephala as Biofuel, Research Journal of Pharmaceutical, Biological and Chemical Sciences ,2013; 4 (1): 515-521

Mohammed RS , Souda SSE, Taie HAA, Moharam ME, Shaker KH, Antioxidant, antimicrobial activities of flavonoids glycoside from Leucaena leucocephala leaves Journal of Applied Pharmaceutical Science, 2015;5(6):138-147.

Negi DS, Sharma RK, Dhasmana P, Negi P, Antifeedent Activity of Some Rutaceae family plants against forest pest/ insects. Acta Ciencia Indica, 2006; 32(3) :209-210

Negi P, Rawat BS, Negi DS , Antifeedant activity of extracts and isolated compounds of two Himalayan plants against a polyphagous pest Spodoptera litura, Octa journal of biosciences, 2016; 4(1): 33-35

Nelson, and William M, 2004. Agricultural Applications in Green Chemistry. Washington D.C., American Chemical Society.

Peta D, Pathipati U, Biological potency of certain plant extracts in management of two lepidopteran pests of Ricinus communis $\mathrm{L}$, Journal of Biopesticides, 2008; 1(2): 170-176.

Pung T, Srimongkolchai W, Asian Journal of Chemistry, 2011; 23, 2863-2865.

Rattan RS, Mechanism of Action of Insecticidal Secondary Metabolites of Plant Origin. Crop Protect., 2010; 29(9): 913-920.

Salem AZM, Salem MZM, Gonzalez-Ronquillo M, Camacho LM, Cipriano M, Major chemical constituents of Leucaena leucocephala and Salix babylonica leaf extracts, Journal of Tropical Agriculture, 2011; 49 (1-2): 95-98.

Selvaraj P, Sahayaraj K, 2008. Effect of Choosen Fern Leaf Extract on the Development of Spodoptera litura. In: Ignacimuthu,S., Jayaraj, S., ed. Green Pesticides for Insect Pest Management. India : NPH, 81-90.

Syamsudin RS, Partomuan S. Antidiabetic activity of active fractions of Leucaena leucocephala (1mk) Dewit seeds in experiment model, European Journal of Scientific Research, 2010; 43 (3): 384-391.

Wheeler, D. A. and Isman, M. B. Antifeedant andtoxic activity of Trichilia americana extract against the larvae of Spodoptera litura. Entomologia Experimentalis et Applicata, 2001; 98: 9-16.

How to cite this article:

Negi P, Rawat BS, Negi DS. Antifeedant Constituents from Leucaena leucocephala. J App Pharm Sci, 2016; 6 (12): 028-031. 